\title{
Individualism, Democracy and Conflict in the USA
}

\author{
Peter Norlander \\ Loyola University Chicago, pnorlander@luc.edu
}

Follow this and additional works at: https://ecommons.luc.edu/business_facpubs

Part of the Business Commons

\section{Author Manuscript}

This is a pre-publication author manuscript of the final, published article.

\section{Recommended Citation}

Norlander, Peter. Individualism, Democracy and Conflict in the USA. International Comparative Employee Relations: The Role of Culture and Language, , : 139-159, 2019. Retrieved from Loyola eCommons, School of Business: Faculty Publications and Other Works,

This Book Chapter is brought to you for free and open access by the Faculty Publications and Other Works by Department at Loyola eCommons. It has been accepted for inclusion in School of Business: Faculty Publications and Other Works by an authorized administrator of Loyola eCommons. For more information, please contact ecommons@luc.edu.

\section{(c) (†) $\ominus$}

This work is licensed under a Creative Commons Attribution-Noncommercial-No Derivative Works 3.0 License. (c) Edward Elgar, 2019. 


\title{
The Growing Divergence in U.S. Employee Relations: \\ Individualism, Democracy, and Conflict
}

\author{
Peter Norlander ${ }^{1}$
}

\begin{abstract}
The growing divergence in U.S. employee relations is described through a review of national and state-level changes to employment protection laws. Major employment laws are reviewed, as are the significant exceptions to the laws, and exemptions to the exceptions. Major regulatory actions, as well as reversals of the regulations, and reversals of the reversals are also described. An analysis of changes to state employment policies since 2000 shows an increasing ideologically driven divergence within the country between left-leaning "equity and voice" states and right-leaning "individual rights and efficiency" states. Instability and divergence are major features of the U.S. system of employee relations that require additional scrutiny.
\end{abstract}

Keywords: Employee relations, employment protection, federalism, divergence

JEL Codes: J50, J80, H77

Draft book chapter prepared for inclusion in International Comparative Employee Relations: The Role of Culture and Language, eds. Pietro Manzella and Karl Koch. Edward Elgar. Forthcoming.

${ }^{1}$ Peter Norlander (pnorlander@luc.edu) is an Assistant Professor at Loyola University Chicago, Quinlan School of Business, 16 E. Pearson St., Ste. 713, Chicago, IL 60611. He thanks Pietro Manzella for helpful guidance and comments. 


\section{International Comparative Employee Relations: The Role of Culture and Language}

The United States has a highly diverse system of labor and employee relations (Katz and Wheeler, 2004). Although it would appear to be joined by a common language, legal system, and history, the employee relations system in the U.S. has a great need for translation, awareness of context, and comparative analysis. As a "human capital" consultant might discuss with the "people operations" leaders in Silicon Valley, the employment relations landscape today is experiencing new challenges requiring greater industry and firm specific knowledge, and awareness of context, local regulations, and cultural differences. As the National Labor Relations Board, the body that oversees labor law, has seen in a number of cases, "language matters" (Manzella and Koch, 2017).

Variety within U.S. employment relations is in part a product of circumstance, and in part, a product of design. The U.S. foreign born population is at its highest level as a proportion of the population in a century, although the growth rate has been decelerating for some time (Norlander and Sørensen, 2018). The challenge of managing in a multicultural and multilingual environment, aside, constitutional federalism is meant to bolster states as "laboratories of democracy," in which policy experimentation is the norm. From a legal standpoint, federal, state, and local governments each have authority to set employment policy, and local activism has been successful in increasing within country variations.

In the mid-1980s, scholars described the decline of stable U.S. employee relations (Kochan, Katz, \& McKersie, 1986). The declining stability was due to changing human resources practices, growing employer resistance to unions, and changing economic circumstances due to intensified foreign competition. The promotion of teams and high performance HR practices, the decline of unions, and increased market competition continue to 
shape U.S. employee relations to this day. As this chapter will discuss, a growing divergence in employment policy within the country since 2000 is a major factor that is decreasing the stability of employee relations today.

Since 2000, stable, yet separate, systems of employee relations have emerged, driven by growing inequality, and political partisanship rooted in cultural divisions. Equity, efficiency and voice have been described as the core objectives at stake in employment relations (Budd, 2004). Today, one system in the U.S. emphasizes the rights of individual employers and employees to establish their own individual bargain, wages, and working conditions, and values individual rights and efficiency in a free labor market. The other system values equity and voice, emphasizing the imbalance of power inherent in the workplace, and advances the rights of a democratic majority to raise wages, set standards, and join unions. Where unified trends once dominated the discussion of employee relations, today, a growing divergence in policy, culture, and workplace relations between two systems is the trend.

Scholars have long written about diverging systems in U.S. employment relations in terms of a primary high-wage system and a secondary low-wage system (Piore, 1972), and more recently in terms of a fissured system between leading firms and their subcontractors (Weil, 2014). At the same time that many U.S. workers benefit from the high-wage system, where high returns to education predominate and global trade has led to greater benefits, nearly twenty percent in the U.S. work in a low-wage system that pays at or below the poverty level, and from which there are reduced opportunities for escape (Osterman, 2008).

While high-wage and low-wage systems co-exist throughout the country, this chapter argues that regional divisions in terms of legal individual rights and democratic rights have increased. Growing partisanship, and the growth of inequality, has led to increased local activism 
on employment policy, leading to a split between "equity and voice" states and "efficiency and individual rights" states.

Long before these recent developments, there were deep historical, cultural, and legal, tensions among American ideals. To many Americans, individual rights are not only protected by the Constitution, but are God-given freedoms: of speech and religion, and association that even democratic majorities cannot remove. In the last several years, voluntary and democratically elected workers' organizations - unions - have been a frequent target of lawsuits on the basis of individual rights to speech and religion. These courtroom conflicts grapple with the competing objectives of the employment relations system, as well as the competing rights of individuals and groups.

Democratic majorities in left-leaning states that support protecting the rights of workers have faced hostile federal courts, and democratic majorities in right-leaning states that oppose unions have passed "right to work" laws that create new individual rights to avoid paying union fees, or "free-ride." In both left and right leaning states, popular referendums raising the minimum wage or supporting unions have been overturned by elected officials, not only on the basis of individual rights protection, but in the interest of diminishing unions' influence on politics.

Conflict between individual rights and democratic majority rights is not new in the U.S., nor is instability in labor and employment relations. A long violent history of bloody battles, electoral and legal contests, over American liberties precedes the present moment. The right to form democratic worker organizations, and the social compact that emerged from those battles was relatively new in U.S. history, a post New Deal phenomena. Its gradual dissolution and the rise of the current period of instability and divergence are in some ways a return to the past. 
Fundamental rights, including the right to join unions without facing termination of employment, to assemble in protest of working conditions, and to picket and boycott are now once again in jeopardy. The historical precedent serves as a reminder that these objectives and conflicting values are not settled, but continually re-forged into a new social contract.

U.S. scholars advocated a post-World War II U.S. system of labor relations as a model for other countries. Near the height of union representation in the U.S., the scholars foretold the arrival of "pluralistic industrialism" around the world due to the logic of industrialization (Kerr, Harbison, Dunlop, \& Myers, 1960). Yet such pluralism, involving accepting the role of multiple stakeholders in the employment relationship, including unions and government regulation, never had a firm hold in certain states within the U.S., and never breached certain anti-union employers, or the gates of paternalistic and generous employers of the welfare capitalist mold (Jacoby, 1998).

Scholars need not travel beyond the U.S. to engage in comparative research, or to find cultural and linguistic factors that shape divergent outcomes. There is enough diversity in the United States' systems of employee relations and types of employment relationships to conduct extensive within-country comparisons, and to generate novel interpretive schemes.

The subject of employee relations includes the conflict among the stakeholders in the employment relationship. The contracts, the actors, and the specific context requires close attention to detail, as well as a broad understanding of the general themes and theories. This chapter will provide an analysis of growing divergence within U.S. employment and labor relations, and the tension between individual rights and democratic majorities.

\section{At-Will Employment and the Market View}


In 2017, 137.9 million workers were employed in the U.S., according to the U.S. Bureau of Labor Statistics. For these workers, however, the conditions of their labor, and the rules under which they work, vary quite starkly when broken into separate areas of U.S. employee relations. While the governing doctrine in the U.S. gives employers wide latitude to set employment policy free of government intervention, exceptions to the laissez-faire norm in the U.S. seek to provide balance by protecting individual and collective rights at work.

The governing doctrine in U.S. employee relations is "employment at-will." Also called "at-will" employment, this term means that, in general, U.S. employees can be fired or laid off at any time, for no reason at all, or for any reason except an illegal one, including bad or arbitrary reasons. Likewise, employees have the right to quit at any time, for any reason, or for no reason at all. While each party has equal rights to terminate the relationship, many argue that the imbalance of bargaining power between employers and employees leads to a potential for abuse.

In general, the terms and conditions of employment agreed to by employee and employer are also at-will; an employer may revise terms and conditions of employment at any time, and a dissatisfied employee can quit. The doctrine of at-will employment is informed by a view of the employment relationship as a market. Under this laissez-faire view, workers freely exchange time and labor for wages. Thus, if wages or working conditions are not favorable, employees can quit their jobs. Under this view, the government should not regulate the labor market, leaving matters instead in the hands of individual employees and employers. This highly individualistic view emerged gradually after the civil war outlawed prevailing exploitative forms of labor. The $13^{\text {th }}$ Amendment to the Constitution banned slavery and indentured servitude, and the $14^{\text {th }}$ Amendment barred the state from depriving any person of "life, liberty, or property, without due process of law..." 
While the emancipatory language of the post-Civil War amendments to the Constitution sought to end the most egregious forms of labor exploitation, new forms of exploitation emerged in the industrial era. Ultimately, these very amendments were used by the Supreme Court to restrict state efforts to improve working conditions. The Supreme Court of the United States ruled unconstitutional state employment regulations that sought to end appalling labor conditions. In the Lochner v. New York (1905) case, a New York law was passed to restrict workers' hours in the interest of health and safety, but the law was ruled unconstitutional under the $14^{\text {th }}$ Amendment because it would limit a worker's liberty to labor for as many hours as the worker desired.

The at-will view of the employment relationship is a deeply held belief in the U.S. Although the Supreme Court eventually reversed the Lochner decision and accepted employment regulation as Constitutional (e.g., West Coast Hotel Co. v. Parrish, 1937) as part of a wave of New Deal legislation in the 1930s, and courts now accept many regulations of the workplace and exceptions to at-will employment, the overarching attitude and deeply ingrained belief in the market view continues to influence employment policy.

This doctrine of at-will employment is quite different from other countries, but as with every other rule in U.S. employee relations, there are large exceptions. Many states, under their own common law or court decisions, have recognized important caveats (Muhl, 2001). Further limits to employment at-will are included in "Labor Law" governing private sector unions and collective rights, and "Employment Law" that governs all workplaces and protect individual rights. Additional exceptions are created in individual employment contracts and employee handbooks. Further, most public sector workers are guaranteed the "due process of law" protected by the $14^{\text {th }}$ Amendment. In addition to these routine exceptions, the political party in 
control of the executive branch regularly makes significant changes in direction and emphasis, destabilizing the system unlike other countries where basic questions tend to be more settled.

The following two sections will illustrate some of these notable exceptions to the at-will doctrine. A word of caution is in order. U.S. policy on labor and employee relations can be very difficult to follow because while there are rules, the rules are governed by a host of exceptions. As the illustrations of the litigiousness of U.S. employment relations below will demonstrate, a lawyer should always be consulted for specific issues. Much of this chapter, and a graduate level course, can discuss those exceptions in detail: the unionized workforce, the public sector civil service, employment discrimination law, and state-level common law.

\section{Employment Law Exceptions}

Employment law is the phrase used to typically describe laws that regulate all U.S. employment relationships, including those involving individually signed employee contracts. Employment law includes anti-discrimination laws such as the Civil Rights Act of 1964, as well as other pieces of protective legislation that create exceptions to employment at will and departures from laissez-faire.

One very active area, wage and hour law, sets minimum labor standards for wages and overtime. Recent activity in the wage and hour law area provides a good example of several phenomena: how exceptions to the laissez-faire doctrine have exceptions themselves, how changing political control leads to major policy changes, how litigious the U.S. system is, and how state-level policy is increasingly diverging within country and from federal policy.

Nearly all workers are covered by the primary wage and hour law in the U.S., the Fair Labor Standards Act (FLSA). The FLSA stipulates that hourly wages must be higher than the federal minimum wage (\$7.25), and that hours worked in excess of 40 hours in a week must be 
paid at 1.5 times the regular hourly rate of the worker. In 2016, 79.9 million workers were paid hourly wages, and by dictating to employers a minimum wage and overtime standards, the FLSA represents a major departure under U.S. law from laissez-faire. However, this exception to the rule has major exceptions.

Exceptions to Exceptions

The terms "exempt" and "non-exempt" are common in reference to wage and hour laws. Many workers are classified "exempt" from overtime requirements, for example, because they are highly paid, earn a salary, and work in a specific occupation that qualifies for an exemption. While the FLSA sets baseline wage and hour standards for the country, large numbers of workers are exempted from both of the central requirements of the law.

For example, some farm and seasonal workers are exempt from minimum wages, and disabled workers, and young workers all carry exceptions. Below the federal minimum wage, there is a legal "sub-minimum” wage for tipped workers $(\$ 2.13)$. The federal minimum wage has eroded in terms of purchasing power significantly, and has not been changed since June of 2009, but states have been active in eliminating or reducing some of these exceptions. Many states and cities have passed higher minimum wages, and several have eliminated the tipped wage discrepancy.

In addition, many workers are exempt from both requirements of the law because they are considered independent contractors and not employees. When workers are incorrectly classified by employers as independent contractors instead of employees, lawsuits are brought seeking damages, a feature of the U.S. system discussed further in the below discussion of litigation and arbitration.

Reversals of Reversals 
A proposed overtime regulation brought forward toward the end of the Obama administration would have significantly increased the number of workers eligible for overtime. Under the proposed regulation, an additional 4.2 million workers would have been automatically eligible for overtime because they earned less than $\$ 47,476$ a year (Department of Labor, 2016). The policy proposal achieved this by increasing the amount of money a worker must be paid to be considered exempt. The goal was to reverse a decline in the number of workers eligible for overtime, which was initially intended to apply to all but a few narrowly drawn exempt workers.

The policy was set to take effect in December 2016. However, because a court challenge brought by the State of Texas, implementation was delayed into 2017. When the new Trump administration arrived, they decided to reverse the regulation, the regulatory change was never implemented.

As an illustration of the consequences of the instability of U.S. employee relations, consider that, in late 2016, companies had communicated to many workers that they would be newly eligible for overtime pay. A month later, companies either faced the choice of rescinding their decision or going forward with a policy that was never implemented. Many workers were left with a promised raise rescinded.

\section{Litigation and Arbitration}

Enforcement of wage and hour laws is generally weak in the U.S. There are far fewer inspectors than needed to investigate all complaints, and so enforcement, when it occurs, is often done via civil litigation (i.e., lawsuits) brought by employees or through settlements between the employer and the Department of Labor. The widespread problem of "wage theft" involves the non-payment of wages owed to workers as required by the FLSA and other statutes. Noncompliance with employment and labor laws in the largest U.S. cities is a substantial 
problem (Bernhardt, Spiller, \& Polson, 2013), and some states and cities have sought to increase criminal enforcement of these laws. Research suggests 2.2 million workers in the U.S. were paid the minimum wage or less, which does not necessarily violate the law given the exceptions noted above (Bureau of Labor Statistics, 2016).

The FLSA applies only to "employees" who an employer "suffers or permits to work." Yet many workers in the U.S. are not employees. Rather, they are independent contractors who run their own business and thus are exempt from the law. Workers can be correctly classified as independent contractors instead of employees if they are running their own business, and possess freedom from employer control. Recent litigation has emphasized the importance of correctly classifying workers as employees.

Consider two workers involved in parcel delivery. The worker who delivers parcels for the U.S. Postal Service is an employee with benefits, a union, and a federal civil service job protecting them from arbitrary termination. If the U.S. Postal Service worker falls sick or is injured, they have insurance that can provide support for them. For much of the last decade, however, a person who delivered parcels through the private company, FedEx Ground, was likely an independent contractor, who did not receive benefits, or pay into the unemployment insurance system. This was the case until a lawsuit challenging the independent contractor status of Fed Ex Ground drivers was settled for \$228 million in California 2016, and \$240 million in 20 other states. ${ }^{1}$

\footnotetext{
${ }^{1}$ Two separate circuit courts found that FedEx misclassified employees. When lower courts agree, parties often settle, but when lower courts disagree, conflict often rises up to higher courts. For the circuit court decisions, see, e.g. Alexander v. FedEx Ground Package System, Inc., 765 F.3d 981 (9th Cir. 2014), and In re FedEx Ground Package System, Inc., 792 F.3d 818 (7th Cir. 2015).
} 
There are significant consequences for employees in the case of a misclassification of an employee as an independent contractor. An employer must pay an employee the minimum wage, and overtime, and also contribute to fund the state unemployment insurance and workers' compensation funds (thus making the employee eligible for these benefits), as well as contributing to federal social security retirement and disability funds (approximately $7.5 \%$ of the wage cost, which again, gives a worker eligibility for these benefits), and provide health insurance under the Affordable Care Act. For independent contractors, none of this is true. Experts suggest large losses to social welfare systems in tax revenue and unemployment and workers' compensation insurance funds due to employees being misclassified as independent contractors.

Employment disputes, as seen in the FedEx case, have long found an outlet in the courtrooms. While individual lawsuits are brought by a single person in cases where they experience wrongdoing, class action lawsuits are typically brought by a small number of employees, yet represent the collective interests of many employees affected by an employer's decision. Such class action lawsuits may be less common in the future, however, due to a recent Supreme Court decision in NLRB v. Murphy Oil USA (2018) that permits employers to force collective issues into individual arbitration.

The traditional litigiousness of U.S. employment relations has been undermined in recent years by the steady rise of a private system of arbitration for individual employment disputes. Arbitration agreements typically require cases to be heard by a private-sector arbitrator, often a retired judge or expert in the employment relations area, who hears the case and renders a final and binding verdict. Such decisions typically cannot be appealed. 
Scholars argue that this emerging system is part of a changing social compact in the U.S. (Lipsky \& Seeber, 2003). Estimates by Alexander Colvin (2014) suggest that 53.9\% of workers are covered by mandatory arbitration clauses. This number is likely to rise. The Murphy Oil case cited above means that employers may now require employees as a condition of continued or new employment to sign a mandatory arbitration agreement that prevents the employee from ever bringing an individual or collective lawsuit before a federal court. Many scholars, and the dissent to this decision written by Justice Ruth Bader Ginsburg, suggest that this increases the imbalance of power toward employers and harkens back to an earlier labor relations era prior to the passage of the National Labor Relations Act.

\section{Labor Relations and Public Employee Exceptions}

Labor relations is the sphere related to the collective rights of workers, especially pertaining to the unionized workforce as well as the rights of unorganized workers to organize labor unions. In Section 7 of the National Labor Relations Act (NLRA), all workers are provided protection from employer retaliation when taking action as a collective to shape their terms and conditions of work. The NLRA further endorses a role for unions and collective bargaining, and requires employers to negotiate in good faith with unions. U.S. labor unions are democratic organizations in which workers elect leaders to negotiate collective bargaining agreements with their employers on their behalf.

The terms and conditions of work for the 14.8 million employed American workers who were union members in 2017 , and the 16.4 million who were covered by union contracts, are governed by clauses contained within negotiated collective bargaining agreements (CBAs) between employers and unions that represent workers. These CBAs are legal contracts that are 
negotiated between workers and individual employers, and unlike many countries, typically cannot be negotiated at the industry or more central level.

At-will employment almost never applies to workers covered by union contracts. Among the most common union contract clauses are specific provisions protecting workers against arbitrary termination. Language in contracts, including just cause clauses, requires employers to have bona fide or legitimate reason for terminating a worker (Dau-Schmidt, \& Haley, 2006). Thus, a separate body of contract law covers union members' rights. Similarly, a separate area of law applies to the 20.7 million American workers in the public sector at the local, state, and federal government, and an additional separate body of law covers 7 million public sector workers in unions. Union and non-union workers employed by the government in civil service positions typically must be given due process of law under the $14^{\text {th }}$ Amendment. This often translates into a requirement that employees have an opportunity to hear reasons for their termination or adverse employment actions, hire an attorney, and to appeal determinations.

Recent years illustrate several patterns in U.S. labor relations: the instability of labor relations policy as political partisanship over labor issues has grown, the rise of individual rights as a courtroom weapon to counter democratic union organization, and the growing divergence within the country.

\section{Instability of Labor Relations}

As in many other countries, unionization has declined significantly in the U.S., falling from $14.9 \%$ in 2000 to $11.8 \%$ in 2017 . In the private sector in 2017 , unionization is at $6.5 \%$. Public sector employees are now the majority of union members, a troubling sign for the union movement, and are also increasingly under attack. 
Unions face very diverse constituencies and have diverse worldviews. Some unions, typically industrial unions, promote broad pro-workers campaigns and advocate social justice. Other unions, typically craft and trade unions, are dedicated to "pure and simple" delivery of services to their members. The schisms among unions have led at times to divisions within the union movement. Most significantly, in 2005, several of the largest unions in the U.S. split from the prevailing federation of U.S. unions, the American Federation of Labor - Congress of Industrial Organizations (AFL-CIO) to form a new coalition "Change to Win."

The Change to Win coalition believed it was necessary to invest more funds in organizing unorganized workers and to lead broad campaigns on behalf of unorganized workers. The Fight for $\$ 15$, a campaign for a $\$ 15$ minimum wage, for example, has been one of the most visible products of these efforts. Beyond organizing workers, the advocacy campaigns and social movements such as the Fight for $\$ 15$ have played a critical role in putting employee relations policy such as minimum wage increases before voters in local referenda.

Alternative forms of labor organization have also increased in the last two decades. Workers centers advocate for workers' rights without organizing workers into unions. They serve the non-union workforce through organizing and advocacy activities that emphasize social justice, workers' rights, and immigrant rights. From 5 workers centers in 1993 to over 200 in 2010, workers centers have joined into national networks to achieve scale, spread knowledge, and build consistent organizing models (Fine, 2011).

The NLRA's Section 7 also protects non-union workers, and despite the decline of unions in the U.S., there has been a variety worker resistance in unlikely places. Individual forms of protest against employers, including absenteeism, shirking, sabotage, and quitting remain popular among U.S. employees. These individualistic protest activities, interestingly, are likely 
to be more present in locations where union representation or a history of collective worker action is absent (Roscigno \& Hodson, 2004).

Unorganized workers have also engaged in collective action. Walkouts and wildcat strikes demonstrate the fundamentally unpredictable nature of labor relations in the U.S. The teacher strike wave that spread across "red states" in the summer of 2018 in response to low wages transformed state level discussion of public education and led to significant wage increases in several states. The Google employee walkout in the fall of 2018 in response to the company's handling of sexual harassment claims brought against senior executives came with demands for employee representation on the board, and policy changes.

\section{Individual Rights Against Collective Rights}

In the last two decades, one of the most dramatic changes has been in terms of "right to work" legislation. These laws give individuals covered by union contracts the right to opt-out of paying union dues. Advocates, in proposing such legislation, state that such right to work laws advance individual freedom. The preamble to a proposed national version of the law states that right to work laws: "Preserve and protect the free choice of individual employees to form, join, or assist labor organizations, or to refrain from such activities." Such laws make the "agency shop," in which workers must pay toward the cost of bargaining and enforcing collective contracts, unlawful. Right to work laws effectively make all unions "open shops," in which workers represented by the union need not pay at all toward the cost of the union.

Critics, however, argue that the "right-to-work" label is misleading. Closed shops that require union membership as a condition of employment are already outlawed under federal law, the Taft-Hartley Act of 1947. The gap between union membership and union coverage suggests that $9.7 \%$ of workers covered by a union contract are not members of their unions. These "free- 
riders" may, however, be required to pay union dues that cover the cost of bargaining their contract if they are not in a right to work state. Advocates of unions criticize right to work laws as undermining unions' ability to exist, and point to the advantages of unions. For example, in comparative research, workers in states with greater union representation tend to have fewer workers at the poverty level, without negative effects on employment (Brady, Baker, \& Finnigan, 2013).

Right-to-work advocates view the open shop as a fundamental issue of individual rights against the collective rights of a majority of workers. Under right to work, while a majority may wish to be represented by a union, that majority should have no right to require any worker who opposes the union to pay for the union's costs. In addition to state-level legislative victories, right-to-work advocates have successfully pursued their case in the federal court system.

Lawsuits brought by public employees, culminating in the recent Supreme Court decision in the Janus v. American Federation of State, County, and Municipal Employees, Council 31 (2018) case, argue that individual workers' right to free speech is impeded by the requirement that government workers spend money on union activities that an individual worker opposes. In Janus, the court ruled against the unions and in favor of workers who oppose unions.

The Janus decision applies today and effectively makes all public sector collective bargaining agreements open shops. The ramifications of this decision are yet to be seen, but it may lead to a further decline in union representation, as fewer workers choose to pay for the cost of union representation. Research has found that states that passed right to work laws experienced a significant increase in voting for conservative elected officials, indicating that the political implications may also be significant (Feigenbaum, Hertel-Fernandez, \& Williamson, 2018). 


\section{Local Democracy and Divergence in U.S. Employee Relations: 2000-2016}

While the above description outlines the contours of the U.S. employment relations system, changes over the last twenty years have led to significant departures from the national norm at the state level. Political polarization has increased in the U.S., and this has been occurring at the state level since 1970 (Grumbach, 2018). Labor and employment policy have been no exception. Conservative states and donor-networks have advocated at the state level for new right to work laws, eliminating prevailing wage laws, and preventing localities from passing or enforcing minimum wage laws (Lafer, 2017). Liberal states and localities have passed minimum wage laws, as advocated by the Fight for $\$ 15$ movement, added resources for wage and hour enforcement, and enacted additional protective measures for workers.

The U.S. employee relations system is ultimately governed by democratic choices, in both federal, state, and local government elections, under a federal constitutional system. Federal statutes set a minimum for labor and employment standards, and states and localities may often set higher standards. At each level, power is balanced between the typically unelected judges who must balance rights in each case, the elected legislators who decide upon the correct laws within the limits of the constitution, and the elected executive branch, which enforces and administers the law through regulatory rule-making and enforcement activity.

In an attempt to measure the change in state-level employment policy since the turn of the century, the below table and figure summarize recent changes within the U.S. to examine whether the description of growing divergence is accurate. In Table 1, the policies used to construct a measure of state-level employment ideology are listed. 
Table 1. State-level employment policy ideology items

\begin{tabular}{|l|l|}
\hline "Left"-leaning state-level legislation & "Right"-leaning state-level legislation \\
\hline Has a state-wide minimum wage law & Pre-empts local minimum wage laws \\
Number of common law exceptions to at- & $\begin{array}{l}\text { Pre-empts local benefits laws } \\
\text { will employment }\end{array}$ \\
Pans on asking for salary history & Pre-empts "fair scheduling" laws \\
Paid sick leave & labor agreements \\
Paid family leave & Right to work laws \\
Sexual orientation anti-discrimination laws & \\
Unemployment compensation system & \\
modernization & \\
\hline
\end{tabular}

Figure 1 presents the change in policy from 2000-2016 on a single left-right ideological scale. Each "right" leaning policy enacted in a state is scored "+1" and each "left" leaning policy "- 1 " to create the ideological scale. Such a single scale can be useful to reduce the complexity of individual policies and understand broad trends in the direction of employment policy. For the purpose of visualization in Figure 1, the values for each state are mean centered at zero. States are sorted from top to bottom from the most "right" leaning to the most "left" leaning in 2016, to better visualize how consistently states have diverged since 2000. Figure 1 demonstrates that divergence has increased within U.S. employment policy since the turn of the century. Statelevel actors have become increasingly active in pushing their local jurisdictions to the left or the right. The following section will discuss the increasing divergence in several key areas. 
Figure 1. Change in State-Level Employment Policy (2000-2016).

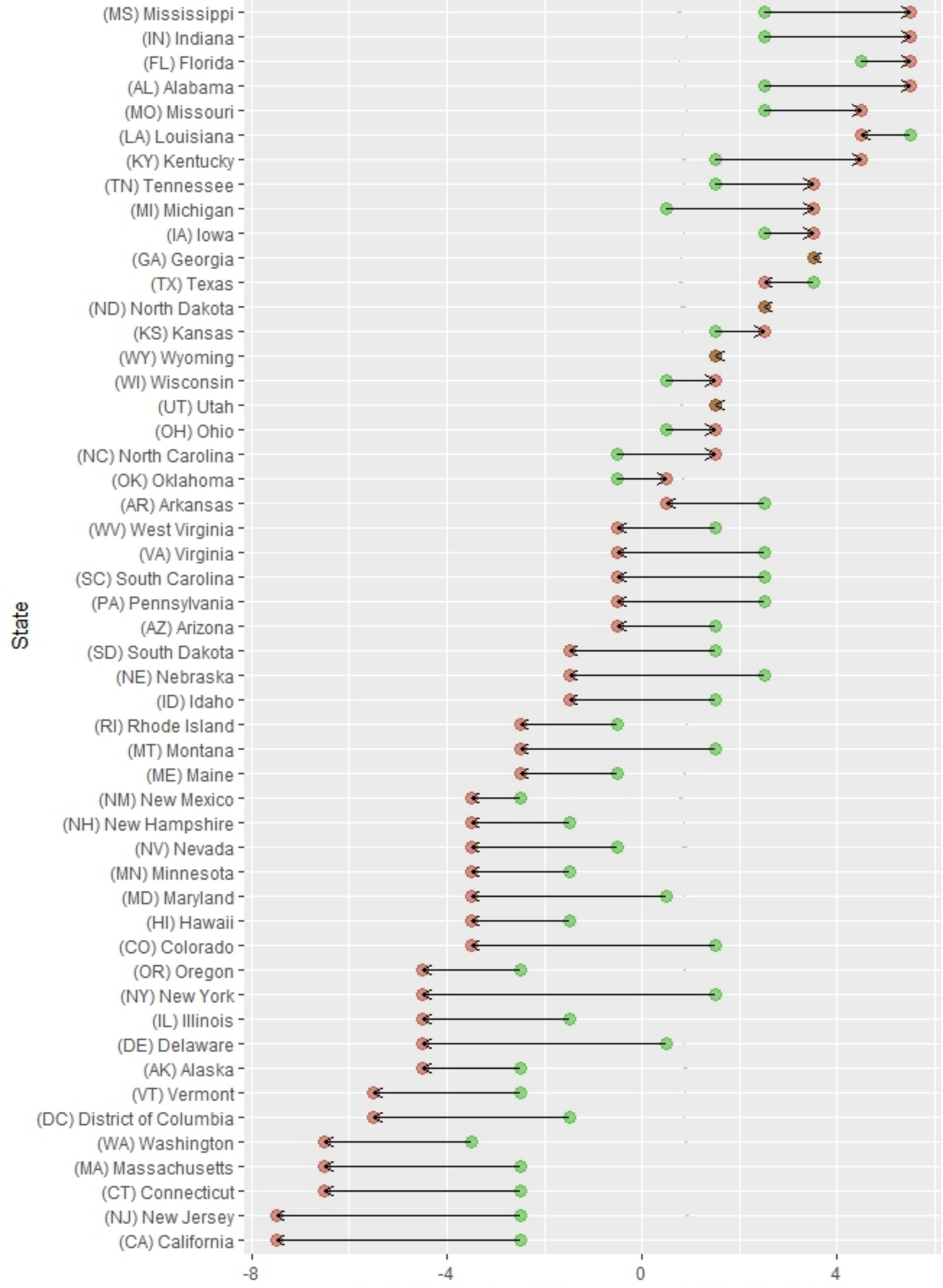




\section{Anti-Discrimination Law Divergence}

An example of growing state level differentiation emerges in another exception to employment-at-will: protections against discrimination. The Civil Rights Act of 1964 was landmark legislation that provided employees protection against discrimination on the basis of an employees' membership in a protected class. Since the passage of the Civil Rights Act, an employer may not alter the terms or conditions of the employment relationship because an employee is a member of a protected class, including race, color, religion, sex, national origin, veteran status, age (over 40), and disability. The federal laws against discrimination have evolved through court rulings to protect workers against sexual harassment, including quid pro quo and hostile work environment harassment. The Equal Employment Opportunity Commission exists to enforce the anti-discrimination laws.

Federal law does not, however, currently prevent employers from discriminating against workers on the basis of sexual orientation or gender identity. Increasingly, states have added protections. State level protections against sexual orientation and gender identity now exist in twenty states (Movement Advancement Project, 2018). As a counter-initiative, several states have also passed laws permitting business owners with deeply held religious beliefs to discriminate against customers (and in Mississippi, workers) if the sexual orientation or identity of the customer/worker is disfavored by the business owner (Human Rights Watch, 2018). Nongovernmental organizations including civil liberties groups, religious organizations, and advocates for gay and lesbian workers have tracked, lobbied, and vocally sought to shape these employment policies.

Benefits Divergence 
The United States is unique among developed nations for not guaranteeing workers any paid leave under federal laws, yet it is not the case that all U.S. workers do not have the right to paid leave. In addition to minimum wage legislation, states and localities have enacted paid sick days, and paid maternity and paternity leave benefits for workers. The first state level paid sick leave law was enacted in 2011; ten states and the District of Columbia now require employers to provide workers paid sick leave. Three states now provide paid family leave through state disability insurance programs.

While some states have been moving toward greater regulation of the labor market, others have taken steps to prevent municipalities within the state from enacting protective labor legislation. For example, sine 1997, 26 states have passed laws that pre-empt (or prevent) a city within the state from enacting a higher minimum wage than state law. St. Louis, Missouri, for example, passed a city ordinance in 2015 to raise the minimum wage to $\$ 10$ per hour in 2017 , and $\$ 11$ per hour in 2018. A state law passed in 2017, however, overturned the city ordinance and denied cities within the state the authority to set minimum wages. Since 2011,21 states have enacted laws that prevent municipalities from enacting benefits legislation such as paid sick days.

\section{Wage and Hour Law Divergence}

Since 2000, protective laws, passed both by elected local and state representatives and through ballot initiatives (a form of direct democracy in which voters vote directly on laws), have increased minimum wages, reduced the sub-minimum wage for tipped workers, created paid sick leave and family leave programs, paid maternity and paternity leave, and placed new emphasis upon the enforcement of wage and hour law and prevention of wage theft. 
The federal minimum wage of $\$ 7.25$ for non-farm and non-tipped workers has not increased since 2009. But where the federal government has not acted, states increasingly have. According to the Bureau of Labor Statistics, in 1988, only 2 states had a minimum wage higher than the federal minimum wage; in 1998, only 6 states required a higher minimum wage; by 2017, 29 states had a higher minimum wage. Eighteen states now automatically increase minimum wages with inflation each year (Economic Policy Institute, 2018). In addition, 42 localities across the U.S. have adopted local minimum wages that are higher than their state minimum wage. The effect of these within-country variations in minimum wages increases has created many "natural experiments," which have been studied extensively (Dube, Lester \& Reich, 2010, 2016).

Under authorities created during the Great Depression, but not used for many years, New York State recently established a wage board to examine labor conditions in the fast food industry, and set a minimum wage of $\$ 15$ for that industry in New York City by December 31, 2018, with lower rates for surrounding counties and for fast food workers outside of the city. Such industry-wide wage setting is not anomalous in U.S. history, but had not been attempted recently until New York's action. States and localities have thus begun to promote different minimum wages for different industries, and localities, and these proposals have attracted national attention as well a potential to serve as model at the federal level (Madland, 2018).

\section{Labor Law Divergence}

Twenty-one states enacted right-to-work legislation between 1944 and 1985 (seventeen between 1944 and 1955). There was no further RTW state law until Oklahoma enacted right-to- 
work in 2001. Since 2012, six more states, including Michigan, Wisconsin, and Missouri have enacted RTW legislation.

Despite these laws passing in the legislature, they have not all been popular. In Wisconsin in 2011, the passage of the law was met with massive protests in the state capitol. A ballot initiative passed by voters repealed Missouri's 2017 right-to-work law in August 2018. Efforts to pass a right to work law in Ohio in 2011 also failed when put before voters in a referendum.

\section{Conclusion}

This chapter illustrates the continued importance of context and regional culture within the U.S. While the market individualism that predominates in the U.S. has been ascendant for some time, some state level actors have increasingly pushed back against this trend through protective employment legislation.

The data presented here demonstrate a growing divergence within U.S. employment policy, as the federal government is increasingly perceived as ineffective at providing desired change. The deeply rooted contests between individualism and democracy, efficiency and equity and voice, have produced repeated conflicts in the courts, and at the ballot box. These trends illustrate the important subnational and regional cultures and the conflict between adherents of individualism and those who favor the collective rights of majorities to democratically set employment policy.

The chapter further sheds light on the critical importance of terminology, as doctrines have exceptions, which have exemptions, which lead to multiple classifications (and misclassifications) of workers. The instability of U.S. employee relations, and the reversals of 
policy that come with changing political control, emphasize the need for professionals to be aware of the specific context of situations in which conflict arises.

\section{REFERENCES}

Bernhardt, A., Spiller, M.W. and Polson, D. 2013. All work and no pay: Violations of employment and labor laws in Chicago, Los Angeles and New York City. Social forces, 91(3), pp.725-746.

BLS Reports, 2016. Characteristics of Minimum Wage Workers, 2016. Bureau of Labor Statistics. Published April 2017. https://www.bls.gov/opub/reports/minimumwage/2016/home.htm

Brady, D., Baker, R.S. and Finnigan, R. 2013. When unionization disappears: State-level unionization and working poverty in the United States. American Sociological Review, 78(5), pp.872-896.

Budd, John W. 2004. Employment with a Human Face: Balancing Efficiency, Equity, and Voice. Ithaca, NY: ILR Press.

Colvin, Alexander, J.S., The Growing Use of Mandatory Arbitration, Economic Policy Institute, September 27, 2017.

Dau-Schmidt, K.G. and Haley, T.A., 2006. Governance of the Workplace: The Contemporary Regime of Individual Contract. Comp. Lab. L. \& Pol'y J., 28, p.313.

Department of Labor, 2016. Overview and Summary of Final Rule: Overtime for White Collar Workers. May 18, 2016. https://www.dol.gov/sites/default/files/overtime-overview.pdf

Dube, A., Lester, T.W. and Reich, M., 2010. Minimum wage effects across state borders: Estimates using contiguous counties. The review of economics and statistics, 92(4), pp.945964.

Dube, A., Lester, T.W. and Reich, M., 2016. Minimum wage shocks, employment flows, and labor market frictions. Journal of Labor Economics, 34(3), pp.663-704.

Economic Policy Institute, 2018. Minimum Wage Tracker. Economic Policy Institute. https://www.epi.org/minimum-wage-tracker/

Feigenbaum, J., Hertel-Fernandez, A., \& Williamson, V. (2018). From the bargaining table to the ballot box: political effects of right to work laws (No. w24259). National Bureau of Economic Research. 
Fine, J., 2011. New forms to settle old scores: updating the worker centre story in the United States. Relations Industrielles/Industrial Relations, 66(4), pp.604-630.

Grumbach, J.M., 2018. From Backwaters to Major Policymakers: Policy Polarization in the States, 1970-2014. Perspectives on Politics, 16(2), pp.416-435.

Human Rights Watch, 2018. Religious Exemptions and Discrimination against LGBT People in the United States. February 19, 2018. See https:/www.hrw.org/report/2018/02/19/all-wewant-equality/religious-exemptions-and-discrimination-against-lgbt-people

Jacoby, S.M., 1998. Modern manors: Welfare capitalism since the New Deal. Princeton University Press.

Katz, H. C., \& Wheeler, H.N., Employment Relations in the United States. In Bamber, G.J., Lansbury, R.D. and Wailes, N. eds., 2004. International and Comparative Employment Relations. SAGE.

Kerr, Clark Harbison, Frederick H., Dunlop, John T. and Charles A Myers. 1960. Industrialism and industrial man. International Labor Review, 82:236.

Kochan, T.A., Katz, H.C. and McKersie, R.B., 1994. The transformation of American industrial relations. Cornell University Press.

Konvitz, M., 2018. Fundamental liberties of a free people: religion, speech, press, assembly. Routledge.

Lafer, G., 2017. The one percent solution: How corporations are remaking America one state at a time. Cornell University Press.

Lipsky, D.B., Seeber, R.L. and Fincher, R.D., 2003. Emerging systems for managing workplace conflict: Lessons from American corporations for managers and dispute resolution professionals (Vol. 18). San Francisco, CA: Jossey-Bass.

Manzella, P., \& Koch, K. (2017). Legal and cultural implications inherent in managing multilingual and multicultural labor: Selected translation issues from the US national labor relations board. Lebende Sprachen, 62(1), 59-78.

Madland, David, 2018. Wage Boards for American Workers: Industry-Level Collective Bargaining for All Workers. Center for American Progress. https://www.americanprogress.org/issues/economy/reports/2018/04/09/448515/wageboards-american-workers/

Movement Advancement Project, 2018. "Non-Discrimination Laws.” See http://www.lgbtmap.org/equality-maps/non_discrimination_laws 
Muhl, Charles J. The employment-at-will doctrine: three major exceptions. Monthly Lab. Rev., $124: 3,2001$

Norlander, P. and Sørensen, T.A., 2018. 21st Century Slowdown: The Historic Nature of Recent Declines in the Growth of the Immigrant Population in the United States. Migration Letters, 15(3), pp.409-422.

Osterman, P., 2008. Improving the quality of low-wage work: The current American experience. International Labour Review, 147(2-3), pp.115-134.

Piore, M.J., 1972. Notes for a theory of labor market stratification.

Roscigno, V.J. and Hodson, R., 2004. The organizational and social foundations of worker resistance. American sociological review, 69(1), pp.14-39.

Weil, D. (2014). The fissured workplace. Harvard University Press. 